\title{
Peningkatan Keterampilan Gerak Lokomotor Melalui Penerapan Model Pendidikan Gerak Format Halang Rintang
}

\author{
Diana Sri Safitri ${ }^{1}$, Agus Mahendra ${ }^{1}$, Didin Budiman', Hanna Amelia ${ }^{2}$, Agus Supriatna ${ }^{2}$ \\ ${ }^{1}$ Program Studi Pendidikan Guru Sekolah Dasar Pendidikan Jasmani, Universitas Pendidikan Indonesia \\ ${ }^{2}$ SDPN 252 Setiabudi Bandung
}

\begin{abstract}
Info Artikel
SejarahArtikel:

Diterima Januari

Disetujui Maret 2018

Dipublikasikan Mei 2018

Keywords:

Pendidikan jasmani, model Pendidikan gerak, halang rintang,,gerak lokomotor.

Abstrak

Penelitian ini didorong oleh masih maraknya proses pembelajaran pendidikan jasmani yang dilakukan dengan cara tradisional, dengan materi ajar yang didominasi oleh keterampilan olahraga formal. Padahal, pendidikan jasmani idealnya lebih menekankan materi kelompok gerak dasar. Sayangnya hal tersebut belum banyak dipraktekkan di Indonesia. Tujuan dari penelitian ini yaitu untuk meningkatkan keterampilan gerak lokomotor siswa kelas 3C SDPN 252 Setiabudi melalui penerapan model pendidikan gerak format halang rintang. Penelitian ini menggunakan metode penelitian tindakan kelas, untuk pengumpulan data menggunakan lembar observasi TGMD-2. Hasil penelitian ini secara keseluruhan rata-rata penguasaan keterampilan gerak meningkat sebesar 9,8 atau jika diprosentasekan sebesar 20,42\%. Sehingga, penerapan model pendidikan gerak format halang rintang dipandang efektif untuk diterapkan pada siswa kelas 3, karena dapat meningkatkan keterampilan gerak lokomotor siswa.
\end{abstract}

\begin{abstract}
The research was driven by the tendency of practice of learning of physical education still conducted in the traditional way, with teaching materials are dominated by formal sports skills. Ideally, Physical education emphasizes the basic movement group components. The purpose of this study is to improve locomotor motor skills of the third grader students of SDPN (Elementary School) 252 Setiabudi through the implementation of the movement education model using the format of "Halang Rintang" (obstacle course). The study employed a classroom action research method, for data collection instrument was using TGMD-2 with a simple modified observation manual. The results of this study in general have shown a little increased average in the mastery of movement skills, greater than 9.8 or other word has increased in percentage around $20.42 \%$. Thus, the implementation of the movement education model using 'obstacle course' format or "Halang Rintang" is considered to be an effective way to improve the basic fundamental skills, especially in the area of locomotor movements and substantially effective to be applied to third grader students.
\end{abstract}




\section{PENDAHULUAN}

Pendidikan jasmani merupakan salah satu alat yang yang digunakan untuk mendidik pada pendidikan formal. Mahendra (2015, hlm. 40) mengemukakan bahwa "Pendidikan jasmani adalah proses pendidikan tentang dan melalui aktivitas jasmani, permainan, dan olahraga yang terpilih untuk mencapai tujuan pendidikan". Menurut pendapat tersebut bahwa pendidikan jasmani merupakan suatu proses untuk mendewasakan seseorang demi mencapai tujuan pendidikan yaitu mencerdaskan kehidupan bangsa melalui aktivitas fisik baik dengan permainan atau dengan olahraga yang terpilih serta kegiatannya melibatkan otot-otot besar. Pendidikan jasmani merupakan mata pelajaran yang tak kalah penting dengan mata pelajaran lain. Melalui pendidikan jasmani, selain domain kognitif domain lain seperti domain afektif dan piskomotornya pun akan berkembang. Pendidikan jasmani merupakan proses pendidikan yang memanfaatkan aktivitas fisik untuk menghasilkan perubahan holistik dalam kualitas individu, baik secara fisik, mental, serta emosional.

Dari hasil observasi yang penulis lakukan di lapangan terdapat permasalahan yaitu guru pendidikan jasmani di kelas bawah melakukan pembelajaran pendidikan jasmani dengan cara cenderung tradisional. Ini terjadi disebabkan oleh tidak adanya kemauan dalam diri guru untuk merubah cara mengajarnya karena guru tersebut sulit untuk mengikuti perkembangan yang ada. Guru mengajarkan olahraga baku kepada anak yang secara logika anak belum mampu melakukan aktivitas sebagaimana ekspetasi yang diharapkan guru. Sehingga sebagian besar siswa merasa kurang tertarik dengan pembelajaran yang dilakukan karena aktivitas pembelaja ran pendidikan jasmani terlalu sulit. Hal ini sejalan dengan hasil pengamatan pada tahun 1999 (dalam Suherman, 2010) "Kondisi pembelajaran pendidikan jasmani di sekolah cenderung berpusat pada guru, siswa hanya menjadi objek pembelajaran, yang tak mendorong potensi diri siswa dalam pembelajaran”. Dengan demikian, pembelajaran pendidikan jasmani belum terlaksana secara maksimal, dan sudah tentu pendidikan jasmani belum mencapai kata ideal, banyak faktor yang mempengaruhi seperti kemampuan guru yang sulit mengikuti perkembangan, kurangnya sikap inovatif pada diri guru pendidikan jasmani untuk mengubah cara penyampaian materinya. Dengan demikian, guru perlu merubah cara mengajarnya.

Banyak model pembelajaran khususnya dalam pembelajaran pendidikan jasmani yang dapat dilakukan guru. Model kurikulum dalam pendidikan jasmani seperti yang disebutkan Mahendra (2015, hlm. 79) "Diantaranya: pendidikan gerak, pendidikan olahraga, pendidikan petualangan, pendidikan perkembangan, pendidikan kebugaran, pendidikan disiplin keilmuan olahraga". Dari macam-macam model kurikulum pendidikan jasmani tersebut, model pendidikan gerak tepat untuk diterapkan di sekolah dasar. Seperti yang diungkap Mahendra (2017) bahwa: Namun demikian, mengingat kelebihan pendidikan gerak yang bukan hanya memberikan kerangka dasar bagi seluruh proses pendidikan jasmani, tetapi juga menjadi dasar bagi seluruh proses pendidikan umum, pendidikan gerak tetap dipandang perlu untuk diterapkan dan diperkenalkan di Indonesia sebagai fondasi penerapan penjas yang lebih menekankan pada perkembangan menyeluruh dari anak, yang meliputi perkembangan kogni- 
tif, perkembangan fisik, serta perkembangan afektifnya (hlm. 4). Dalam model pendidikan gerak ini tidak diperkenalkan kecabangan olahraga, tetapi anak diperkenalkan keterampilan gerak dasar yang menekankan pada konsep dan komponen gerak. Model pendidikan gerak dapat menumbuhkan rasa berhasil pada diri setiap anak, karena pembelajaran model pendidikan gerak disesuaikan dengan perkembangan dan usia anak. Model pendidikan gerak bersifat eksploratif, karena guru tidak dianjurkan untuk memberi contoh, tetapi anak mencari sendiri gerakan apa yang harus dilakukan dan melakukannya sesuai dengan kemampuan anak, sehingga menjadikan anak selain aspek psikomotor berkembang, berkembang pula aspek kognitifnya. Dari sisi isi materi, yang banyak digunakan dalam pembelajaran pendidikan jasmani sekolah dasar yaitu pola gerak dasar. Gerak dasar tersebut merupakan dasar macammacam keterampilan yang sangat perlu adanya bimbingan, latihan, dan pengembangan, agar anak dapat melaksanakan keterampilan tersebut dengan baik.

\section{METODE PENELITIAN}

\section{Desain Penelitian}

Penelitian ini dilakukan dengan Penelitian Tindakan Kelas (PTK) atau Classroom Action Research. Menurut David Hopkins, 1993, Kemmis, 1982, dan Mc Taggart, 1991 (dalam Tampubolon, 2014, hlm. 19) "Penelitian tindakan kelas merupakan bentuk strategi dalam mendeteksi dan memecahkan masalah yang dihadapi pendidik dengan tindakan nyata, yaitu melalui prosedur penelitian yang berbentuk siklus (daur ulang)". Penelitian tindakan kelas ini digunakan sebagai alat untuk memecahkan masalah-masalah pembelajaran di dalam kelas melalui tindakan penelitian agar pembelajaran yang dilaksanakan lebih baik.

\section{Partisipan}

Partisipan atau subjek penelitian merupakan peserta didik di kelas 3C SDPN 252 Setiabudi Bandung, dengan jumlah 34 peserta didik yang terdiri dari 18 peserta didik laki-laki dan 16 peserta didik perempuan. Siswa kelas tiga perlu adanya bimbingan dan arahan untuk mencapai keterampilan gerak yang baik. Karena seperti yang diungkap Sukintaka (1992, hlm. 42) yaitu "Kelas tiga yang rata-rata berusia antara 9-10 tahun memiliki karakteristik jasmani yaitu memerlukan perbaikan kordinasi dalam keterampilan gerak".

\section{Instrumen Penelitian}

Instrumen merupakan alat yang dipakai untuk mengumpulkan data selama penelitian. Menurut Arikunto (2010, hlm. 203) "Instrumen penelitian adalah alat atau fasilitas yang digunakan oleh peneliti dalam mengumpulkan data agar pekerjaannya lebih mudah dan hasilnya lebih baik, dalam arti lebih cermat, lengkap, dan sistematis sehingga lebih mudah diolah". Dalam penelitian ini alat yang dipakai untuk mengumpulkan data yaitu:

Lembar observasi. Lembar observasi yang digunakan berupa Test of Gross Motor Development-2 (TGMD-2) yang diadopsi dari Dale A Ulrich. TGMD-2 ini memiliki total 12 item tes keterampilan yaitu 6 tes keterampilan lokomotor dan 6 tes keterampilan objectcontrol. Namun, dalam penelitian ini hanya menggunakan 6 tes keterampilan lokomotor. Cara memberikan skor pada lembar observasi TGMD-2 tersebut menggunakan sistem ceklis (V). Jika siswa melakukan kriteria dengan tepat maka diberi tanda ceklis pada kolom (trial 1 
atau trial 2) dan mendapat skor 1. Jika siswa tidak melakukan kriteria dengan tidak tepat maka tidak diberi tanda ceklis pada kolom (trial 1 atau trial 2) dan mendapat skor 0.

Catatan lapangan. Catatan lapangan adalah beberapa catatan yang diperoleh peneliti mengenai hasil pengamatan pada saat penelitian untuk mendapatkan data yang sedetail mungkin, sehingga proses penelitian dapat berjalan secara efektif dan efisien dalam setiap tindakan -tindakan pada saat proses belajar mengajar berlangsung.

\section{Analisis Data}

Menurut Sugiyono (2016, hlm. 207) "Analisis data merupakan kegiatan setelah data dari seluruh responden atau sumber data lain terkumpul". Karena hasil dari analisis data nanti akan ditarik kesimpulan dan hanya berlaku untuk sampel bukan populasi maka teknik analisis data yang digunakan dalam penelitian ini yaitu menggunakan statistik deskriptif. Menurut Sugiyono (2016, hlm. 207) "Statistik deskriptif adalah statistik yang digunakan untuk menganalisis data dengan cara mendeskripsikan atau menggambarkan data yang telah terkumpul sebagaimana adanya tanpa bermaksud membuat kesimpulan yang berlaku untuk umum atau generalisasi”. Adapun langkah yang ditempuh yaitu : menjumlahkan skor yang diperoleh pada masing-masing item yang dinilai (run, gallop, hop, leap, horizontal jump, dan slide); merubah jumlah skor yang diperoleh (skor baku) menjadi skor standar dan presentil; mencari kategori dari setiap skor yang diperoleh siswa untuk mengetahui penguasaan keterampilan gerak lokomotor siswa.

\section{HASIL PENELITIAN}

Dari hasil penelitian terhadap penguasaan keterampilan gerak lokomotor siswa melalui penerapan model pendidikan gerak format halang rintang, terdapat hasil dari data awal hingga siklus 2 yang disajikan pada diagram berikut:

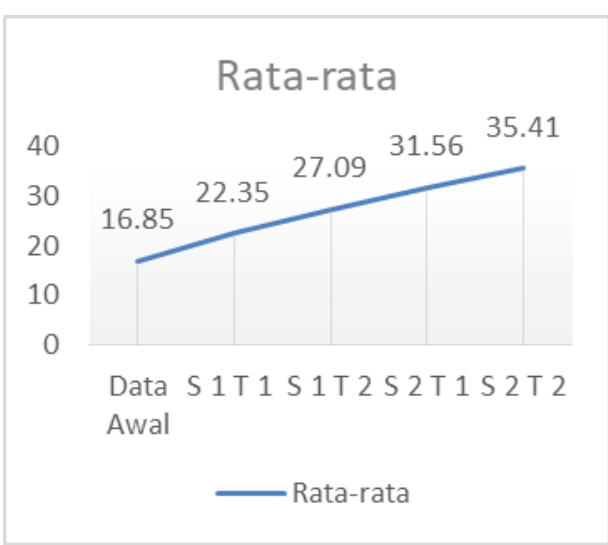

\section{Diagram 1. Perbandingan Rata-rata Setiap Tindakan}

Pada data awal (pre-test) terdapat ratarata sebesar 16,85 atau jika diprosentasekan sebesar 35,10\%. Pada hasil siklus 1 tindakan 1 mengalami peningkatan rata-rata sebesar 5,5 atau sebesar 11,55\%, yaitu menjadi sebesar 22,35 atau jika diprosentasekan sebesar $46,56 \%$. Begitu pun pada tindakan selanjutnya yaitu hasil dari siklus 1 tindakan 2 mengalami peningkatan rata-rata sebesar 4,74 atau sebesar 9,87\% yaitu menjadi 27,09 atau jika diprosentasekan sebesar 56,43\%. Hasil tersebut didapat karena siswa mulai memahami dan terbiasa dengan materi yang diberikan. Kemudian peneliti melanjutkan penelitian, karena jika dilihat dari kategori yang didapat masih banyak siswa yang termasuk dalam kategori sangat rendah. Pada siklus 2 tindakan 1 terdapat rata-rata sebesar 31,56 atau jika diprosentasekan sebesar $65,75 \%$. Selanjutnya rata-rata dari siklus 2 tindakan 2 sebesar 35,41 atau jika diprosentasekan sebesar $73,77 \%$, sehingga terdapat peningkatan 
rata-rata sebesar 3,85 atau sebesar 8,02\%. Pada penelitian siklus 2 tindakan 2 sebagian besar siswa kelas $3 \mathrm{C}$ dapat memahami dan bisa mempraktikkan gerak lokomotor, hal tersebut dapat dilihat dari kategori yang didapat siswa.

Selain itu, terdapat perbandingan data keseluruhan. Data keseluruhan merupakan gabungan yang dirata-ratakan dari hasil setiap tindakan, dan jika dibandingkan dengan data awal maka secara keseluruhan hasilnya mengalami peningkatan. Hal ini dapat dilihat pada diagram berikut:

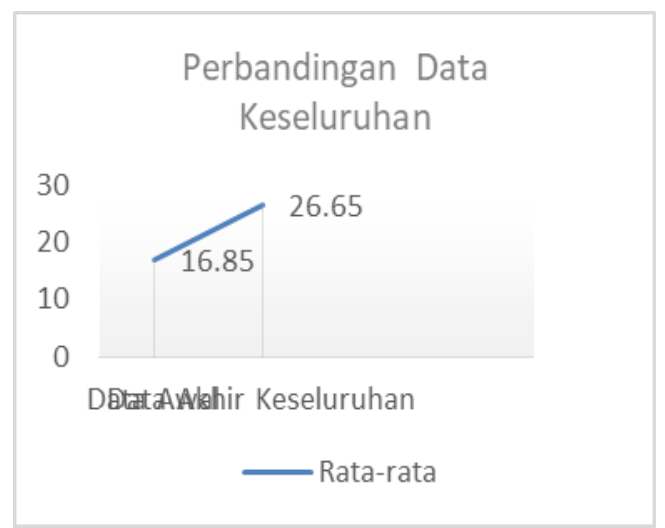

Diagram 2. Perbandingan Data Keseluruhan

Data siklus 1 dan 2 dirata-ratakan menjadi sebesar 26,65 atau sebesar 55,52\%, dan jika dibandingkan dengan data awal sebesar 16,85 atau sebesar $35,10 \%$, maka secara keseluruhan rata-rata penguasaan keterampilan gerak lokomotor siswa meningkat sebesar 9,8 atau sebesar 20,42\%. Jadi, dapat disimpulkan bahwa penerapan model pendidikan gerak format halang rintang dapat meningkatkan keterampilan gerak lokomotor siswa.

\section{DISKUSI PENEMUAN}

Ketika melakukan observasi ke lapangan, peneliti menemukan berbagai masalah yaitu kurangnya pengetahuan tentang pengertian ser- ta macam-macam gerak lokomotor, konsep gerak, karena pada saat pembalajaran pendidikan jasmani guru masih menerapkan model pembelajaran secara langsung serta kurangnya penjelasan terhadap materi yang diajarkan. Seperti yang diungkap Afandi, dkk (2013, hlm. 16) "Pembelajaran langsung dapat didefinisikan sebagai model pembelajaran di mana guru mentansformasikan informasi atau keterampilan secara langsung kepada peserta didik, pembelajaran berorientasi pada tujuan dan distrukturkan oleh guru". Model ini lebih berorientasi kepada guru dan siswa hanya mengikuti perintah guru yang telah disusun oleh guru. Dalam hal ini peneliti mencoba untuk menerapkan atau mengenalkan model pendidikan gerak format halang rintang sebagai salah satu pendekatan dalam pembelajaran pendidikan jasmani, yang bertujuan untuk meningkatkan keterampilan gerak lokomotor siswa. Dengan melihat hasil penelitian terdapat empat temuan yaitu sebagai berikut:

\section{Siklus 1 Tindakan 1}

Pada siklus 1 tindakan 1 terjadi peningkatan rata-rata sebesar 5,5 atau sebesar 11,46\% dari data awal. Hal ini terjadi karena dalam melakukan gerak lokomotor siswa menggunakan informasi tentang bagaimana pelaksanaan suatu keterampilan, dari enam tes item lokomotor hanya beberapa macam gerak lokomotor saja yang dapat dilakukan, karena siswa masih belum terlalu paham tentang gerak lokomotor serta macam-macam gerakannya, sehingga belum terjadi perubahan yang signifikan, pengalaman gerak anak belum dilakukan secara bermakna. 


\section{Siklus 1 Tindakan 2}

Pada siklus 1 Tindakan 2 terjadi peningkatan rata-rata sebesar 10,24 atau sebesar $21,33 \%$ dari data awal. Hal ini karena siswa mulai mengetahui macam-macam gerak lokomotor dan cara melakukannya, setelah diberi pengulangan materi yang sebelumnya. Pada tahapan ini siswa mulai terbiasa melakukan hampir semua item gerak lokomotor tetapi terkadang masih bertanya cara melakukan suatu gerakan dan masih memerlukan waktu yang cukup untuk melakukan pengulangannya.

\section{Siklus 2 Tindakan 1}

Pada siklus 2 tindakan 1 terjadi peningkatan rata-rata sebesar 14,71 atau sebesar $30,65 \%$ dari data awal. Hal ini karena siswa mulai mengetahui semua macam keterampilan gerak lokomotor dan cara melakukannya. Pada tahapan ini, ketika diberi intruksi melakukan gerak lokomotor siswa langsung melakukannya tanpa berfikir panjang tentang apa yang akan dilakukan dan bagaimana cara melakukannya.

\section{Siklus 2 Tindakan 2}

Pada siklus 2 tindakan 2 terjadi peningkatan rata-rata sebesar 18,56 atau sebesar $38,67 \%$ dari data awal. Hal ini karena siswa sudah memahami terkait konsep gerak lokomotor, macam-macam gerak lokomotor serta cara melakukannya. Siswa dapat melakukan gerak lokomotor dengan kordinasi yang cukup baik, dan ketika siswa diminta untuk melakukan suatu keterampilan gerak lokomotor, siswa dapat langsung melakukannya. Perubahan pada siklus 2 dapat dikatakan signifikan jika dilihat dari hasil observasi yang didapat.

Jika dilihat dari hasil temuan setiap tindakan dapat mempengaruhi penguasaan keterampilan gerak lokomotor siswa tahap demi tahap. Seperti yang dirangkum dalam Juliantine, dkk. (2016, hlm. 133) bahwa tahapan belajar gerak meliputi tahap kognitif, tahap asosiatif, dan tahap otomatisasi. Dalam tahap kognitif, siswa masih melakukan suatu gerakan dengan informasi yang didapatkan dari penjelasan guru tentang apa dan bagaimana suatu gerakan dilakukan. Dalam tahap asosiatif, siswa mulai berkonsentrasi pada pola gerak dan penghalusan gerak, serta siswa masih memerlukan waktu cukup lama dalam melakukan pengulangan suatu ketermpilan gerak. Dalam tahap otomatisasi, siswa sudah dapat melakukan suatu keterampilan gerak secara otomatis, artinya anak sudah tahu apa yang harus dilakukan dan bagaimana cara melaukannya.

Berdasarkan hasil temuan penelitian pada siklus 1 dan 2, dalam pelaksanaan pembelajaran pendidikan jasmani menggunakan model pendidikan gerak format halang rintang memiliki kelebihan yaitu dapat menarik perhatian siswa dalam mengikuti pembelajaran pendidikan jasmani karena banyak media yang digunakan, siswa juga lebih kreatif, dan siswa dapat mengembangkan keterampilan yang dimiliki sesuai kemampuannya masing-masing, serta membuat semua siswa bergerak secara aktif.

Kemudian, perlu diadakan perbaikan dalam pembelajaran pendidikan jasmani menggunakan model pendidikan gerak format halang rintang, diantaranya dalam penggunaan media yang digunakan lebih ditingkatkan dan lebih bervariasi supaya lebih menarik perhatian siswa, berikan penjelasan materi yang diajarkan dengan jelas, serta guru lebih komunikatif dengan siswa. 


\section{KESIMPULAN}

Berdasarkan hasil penelitian yang dilakukan pada siswa kelas 3C SDPN 252 Setiabudi dapat disimpulkan bahwa penerapan model pendidikan gerak format halang rintang dapat meningkatkan keterampilan gerak lokomotor siswa. Penggunaan format halang rintang dalam pendidikan gerak dianggap cukup efektif untuk meningkatkan keterampilan gerak lokomotor, dibandingkan struktur pergerakan bebas dan struktur berpola. 


\section{DAFTAR PUSTAKA}

Afandi, M. chamalah, E. Wardani,P,O. (2013). Model Dan Metode Pembelajaran Di Sekolah. Semarang: UNISSULA PRESS. ISBN: 9786027525641.

Arikunto, S. (2010). Prosedur Penelitian Suatu Pendekatan Taktis. Jakarta: Rineka Cipta.

Juliantine, T. Subroto, T. Yudiana, Y. (2016). Belajar Dan Pembelajaran Pendidikan Jasmani. Bandung:FPOK UPI.

Mahendra, A. (2015). Buku Ajar Filsafat Pendidikan Jasmani. Bandung:CV Bintang WarliArtika.

Mahendra, A. (2017). Model Pendidikan Gerak Implementasi Pendidikan Jasmani di Sekolah Dasar. Bandung: Red Point.

Sugiyono. (2016). Metode Penelitian Pendidikan (Pendekatan Kuantitatif, Kualitatif, dan R\&D). Bandung: Alfabeta.

Suherman, A. (2010). Model Pembelajaran PAKEM Dalam Pendidikan Jasmani Di Sekolah Dasar. Jurnal Penelitian Pendidikan, 11(1), 131-141.

Sukintaka. (1992). Teori Bermain. Departemen Pendidikan dan Kebudayaan Direktorat Jenderal Pendidikan Tinggi Proyek Pembinaan Tenaga Kependidikan.

Tambulon, M, S. (2014). Penelitian Tindakan Kelas. Jakarta: Erlangga.

Ulrich, A, D. (t.t). Test Of Gross Motor Development Second Edition. [Online]. Diakses dari http://33202576.weebly.com/ uploads/1/4/6/8/14680198/tgmd-2-2.pdf. 